\title{
RISK FACTORS FOR INDICATIONS OF INTRAOPERATIVE BLOOD TRANSFUSION AMONG PATIENTS UNDERGOING SURGICAL TREATMENT FOR COLORECTAL ADENOCARCINOMA
}

\author{
Iara GONÇALVES ${ }^{1}$, Marcelo LINHARES ${ }^{2}$, Jose BORDIN ${ }^{3}$ and Delcio MATOS ${ }^{1}$
}

\begin{abstract}
Context - Identification of risk factors for requiring transfusions during surgery for colorectal cancer may lead to preventive actions or alternative measures, towards decreasing the use of blood components in these procedures, and also rationalization of resources use in hemotherapy services. This was a retrospective case-control study using data from 383 patients who were treated surgically for colorectal adenocarcinoma at "Fundação Pio XII", in Barretos-SP, Brazil, between 1999 and 2003. Objective - To recognize significant risk factors for requiring intraoperative blood transfusion in colorectal cancer surgical procedures. Methods Univariate analyses were performed using Fisher's exact test or the chi-squared test for dichotomous variables and Student's $t$ test for continuous variables, followed by multivariate analysis using multiple logistic regression. Results - In the univariate analyses, height $(P=0.06)$, glycemia $(P=0.05)$, previous abdominal or pelvic surgery $(P=0.031)$, abdominoperineal surgery $(P<0,001)$, extended surgery $(P<0.001)$ and intervention with radical intent $(P<0.001)$ were considered significant. In the multivariate analysis using logistic regression, intervention with radical intent $(\mathrm{OR}=10.249, P<0.001,95 \% \mathrm{CI}=3.071-34.212)$ and abdominoperineal amputation $(\mathrm{OR}$ $=3.096, P=0.04,95 \% \mathrm{CI}=1.445-6.623)$ were considered to be independently significant. Conclusion - This investigation allows the conclusion that radical intervention and the abdominoperineal procedure in the surgical treatment of colorectal adenocarcinoma are risk factors for requiring intraoperative blood transfusion.
\end{abstract}

HEADINGS - Blood transfusion. Colorectal neoplasms, surgery. Adenocarcinoma, surgery.

\section{INTRODUCTION}

Colorectal adenocarcinoma is the fourth most frequent neoplasm in women and the fifth most frequent neoplasm in men in Brazil, with an estimative of 26,990 new diagnosis in $2008^{(8)}$.

In cases of colorectal adenocarcinoma, the most important type of treatment involves surgical procedures ${ }^{(4,}$ 5). Transfusions of blood components often become necessary during the operation ${ }^{(9,10)}$. However, blood transfusions are not free of risks, and among these are the transmission of infectious diseases ${ }^{(3)}$, allergic reactions, red blood cells alloimunization, hemolytic reactions and immunosuppression ${ }^{(1)}$.

This retrospective study was conducted at "Fundação Pio XII", in Barretos, SP, Brazil, with the aim to recognize significant risk factors for requiring intraoperative blood transfusion in colorectal cancer surgical procedures.
This knowledge will turn possible the standardization of alternative measures, such as autologous blood transfusion $^{(7)}$, or preventive actions, such as perisurgical erythropoietin application ${ }^{(6)}$ or iron replacement for those patients with iron deficiency ${ }^{(12)}$, in order to diminish the use of allogeneic blood transfusions. In cases where this reduction is not possible, the information obtained with this study will allow to better plan the blood bank service, orientating the blood schedules for specific surgical procedures, avoiding the costs generated by unnecessary crossmatch tests and by the decrease in storage time that occurs each time a red blood unit is held for a patient that does not use it.

\section{Literature}

Regardless its importance, only two studies have been conducted with the intention of identifying the risk factors for transfusion in surgical colorectal or

'Department of Hematology and Hemotherapy, Fundação Pio XII, Barretos, SP, Brazil; '2Department of Surgery, Discipline of Surgical Gastroenterology and ${ }^{3}$ Discipline of Hematology and Hemotherapy, Federal University of São Paulo, São Paulo, SP, Brazil

Correspondence: Dr. lara Gonçalves - Fundação Pio XII - Rua Antenor Duarte Vilela, 1331 - 14784-400 - Barretos, SP, Brazil. E-mail: izap@uol.com.br 
rectal cancer patients, neither of them studied colorectal cancer patients of a single institution.

One of these studies ${ }^{(1)}$ has been a data based study, with patients of 52 different institutions, and they could identify age, gender, comorbidity and metastatic disease, and hospital and surgeon related characteristics as risk factors for transfusion. The other study ${ }^{(2)}$ has been conducted in a single institution, with rectal cancer patients; age, body mass index, hemoglobin, ASA status and other procedures were indicated as risk factors for transfusion in this study.

\section{METHODS}

\section{Patients}

The data in the medical files of 383 patients who were admitted to "Fundação Pio XII", for treatment of colorectal adenocarcinoma between 1999 and 2003 were analyzed. All the patients were aged over 18 years, had a confirmed diagnosis of colorectal adenocarcinoma from anatomopathological examination and underwent surgery to treat the colorectal cancer in this institution. Patients who underwent local transanal resection surgery or for whom data relating to intraoperative transfusions could not be retrieved were excluded. Some of the data on the patients and the surgery undertaken are shown in Table 1.

TABLE 1. Patient distribution according to gender, age, body mass index, clinical staging, tumor location and type of surgery performed

\begin{tabular}{|c|c|c|c|}
\hline Variable & $\begin{array}{c}\text { Total sample* } \\
\text { (383) }\end{array}$ & $\begin{array}{c}\text { Transfused* } \\
(178)\end{array}$ & $\begin{array}{l}\text { Not transfused } \\
(205)\end{array}$ \\
\hline Gender $\left(\mathrm{M}^{\dagger} / \mathrm{F}^{\ddagger}\right)$ & $201 / 182$ & $99 / 79$ & $102 / 103$ \\
\hline Age (years) & $59.73 \pm 13.41$ & $59.24 \pm 12.80$ & $60.12 \pm 13.93$ \\
\hline $\operatorname{BMI}^{\S}\left(\mathrm{kg} / \mathrm{m}^{2}\right)$ & $24.71 \pm 4.75$ & $24.82 \pm 4.76$ & $24.63 \pm 4.77$ \\
\hline TNM (0, I, II/III, IV) & $199 / 184$ & $101 / 77$ & $98 / 107$ \\
\hline Location (colon/rectum) & $202 / 179$ & $91 / 87$ & $111 / 92$ \\
\hline \multicolumn{4}{|l|}{ Type of operation performed } \\
\hline Segmental colectomy & 259 & 114 & 145 \\
\hline Total colectomy & 14 & 12 & 2 \\
\hline $\mathrm{APRR}^{\ddagger}$ & 42 & 31 & 11 \\
\hline Palliative surgery & 50 & 5 & 45 \\
\hline Extended surgery & 18 & 18 & 0 \\
\hline $\begin{array}{l}\text { *N (number) if categorical variable, } \\
\text { M: male } \\
{ }^{*} \text { F: female } \\
\text { s body mass index } \\
{ }^{\prime} \text { abdominoperineal resection of the }\end{array}$ & SD if continuous $v$ & & \\
\hline
\end{tabular}

One hundred and nine patients $(28.46 \%)$ underwent neoadjuvant oncological procedures. Of these, $75(68.80 \%)$ underwent neoadjuvant chemotherapy and radiotherapy (CT + RT). All patients underwent pre-anesthesia cardiological assessment and were classified according to Goldman's index. For 339 patients $(88.51 \%)$, the operation was elective. For 333 patients $(86.95 \%)$, the operation had radical intent, while for $50(13.05 \%)$ it had palliative intent.

With regard to tumor location, 203 patients (53\%) presented neoplasia in the colon $(34.20 \%$ in the left colon and $18.80 \%$ in the right colon) and $178(46.48 \%)$ presented neoplasia in the rectum $(26.89 \%$ in the proximal rectum and $19.59 \%$ in the distal rectum).

\section{Statistics}

The independent variables of age, gender, weight, height, body mass index, hemoglobin, creatinine, glycemia, arterial pressure, tumor location, surgery performed, history of previous abdominal or pelvic surgery, use of neoadjuvant oncological treatment, surgeon responsible, emergency versus elective surgery, clinical staging (TNM) and surgical risk were correlated with the dependent variable of transfusion of red blood cell concentrates during the surgery, by means of univariate analysis.

Pearson's chi-squared test (or Fisher's exact test when required) and Student's $t$ test were utilized, respectively for the categorical and continuous variables.

To determine the factors that were related to blood transfusion, the dependent variables that presented significance in the univariate analyses (Pearson's chi-squared or Fisher's exact or Student's $t$ test) were analyzed together, using the multivariate analysis technique of multiple logistic regression.

Initially, a significance level of $0.10(P \leq 0.10)$ was taken for inclusion in the multivariate analysis model. The variables that, although not reaching significance in the univariate analysis $(P \leq 0.10)$, were considered to be relevant according to data in the literature were also subjected to multivariate analysis.

In the final model, the significance level set was $P<0.05$.

The statistical analyses were performed on an IBMcompatible computer, by means of the SPSS version 13.0 statistical package (SPSS Statistical Software, Inc).

\section{RESULTS}

One hundred and seventy-eight patients $(46.48 \%)$ received transfusions of red blood cell concentrates: $108(60.6 \%)$ of these patients received one unit of red blood cell concentrate; $50(28.1 \%)$ received two units and only $2(1.1 \%)$ received more than five units.

In the univariate analyses, the significance level taken was $0.10(P \leq 0.10)$. Thus, the following variables were considered to be significant: glycemia $(P=0.05)$, height $(P=0.06)$, previous abdominal or pelvic surgery $(P=0.031)$, extended surgery $(P<0,001)$, abdominoperineal amputation of the rectum $(P<0.001)$ and radical intent $(P<0.001)$.

In the multivariate analysis using logistic regression, the following variables were considered to be independently significant in this sample, in relation to increased risk of requiring blood transfusion: surgery with radical intent and abdominoperineal amputation of the rectum, as shown in Table 2.

TABLE 2. Final result from multiple logistic regression model for transfusion of red blood cell concentrate

\begin{tabular}{lcccc}
\hline Variables & $\begin{array}{c}\text { Regression } \\
\text { coefficient }\end{array}$ & $\begin{array}{c}\text { Significance } \\
\text { level }\end{array}$ & OR $^{*}$ & 95\% $\mathbf{C I}^{\dagger}$ \\
\hline APRR ${ }^{\ddagger}$ & 1.130 & 0.04 & 3.096 & $1.445-6.623$ \\
Radical intent & 2.327 & $<0.001$ & 10.249 & $3.071-34.212$ \\
Constant & -1.298 & 0.70 & - & - \\
\hline $\begin{array}{l}* \text { odds ratio } \\
{ }^{\dagger} \text { confidence interval } \\
\ddagger \text { abdominoperineal resection of the rectum }\end{array}$ & & & \\
\end{tabular}




\section{DISCUSSION}

Despite the importance of knowing the risk factors for requiring transfusion during operations for treating colorectal adenocarcinoma, only two similar studies ${ }^{(2,11)}$ were carried out previously. Neither of these was on patients with colorectal adenocarcinoma in a single institution.

Knowledge of these risk factors may lead to preventive actions $^{(6,12)}$ or alternative measures ${ }^{(7)}$, towards decreasing the use of blood components in these procedures, and may give rise to better planning of hemotherapy services.

On the basis of the results from this investigation, we can conclude that surgical intervention of radical nature and the procedure using abdominoperineal access, for the surgical treatment of colorectal adenocarcinoma, constitute independent risk factors for indicating intraoperative blood transfusion.

Operations with radical intent tend to lead to resections for which the extent is proportional to the staging grade, given that resection with free margins is fundamental for treating colorectal adenocarcinoma. On the other hand, palliative surgery commonly consists of operations of smaller extent, with the purpose of relieving the symptoms or delaying the clinical manifestations that results from the evolution of the disease.

Thus, the increased risk of bleeding and consequent increased risk of requiring intraoperative blood transfusion are explained through the size of the operation, as found in this investigation.
The type of operation performed (abdominal or abdominoperineal access) greatly modifies the size of the procedure, with implications for the level of risk from a surgical point of view. Thus, in abdominoperineal interventions, and particularly in relation to lesions with advanced staging, the dissections are more extensive. They involve ligature of vascular pedicles of greater caliber and are frequently performed alongside the presacral fascia, where the hemostasis procedure may be very insecure, given the intra-osseous anatomical position (sacral foramina) of the tributaries of the middle sacral vein.

All these characteristics described here increase the risk of local bleeding and therefore give rise to greater necessity for intraoperative blood transfusion. The results obtained from this investigation corroborate these assertions through the demonstration the importance of the risk factor of abdominoperineal amputations of the rectum.

\section{CONCLUSION}

Therefore, among patients who undergo surgery with radical intent, and especially among those with an indication for abdominoperineal amputation of the rectum, attention must be given to the increased risk of requiring blood transfusion, and alternative procedures should be sought when possible or indicated.

Gonçalves I, Linhares M, Bordin J, Matos D. Fatores de risco para indicação de transfusão sanguínea intraoperatória em doentes operados por adenocarcinoma colorretal. Arq Gastroenterol. 2009;46(3):190-3.

RESUMO - Objetivo - Identificar fatores de risco de indicação de transfusão sanguínea intraoperatória em doentes submetidos a tratamento cirúrgico por adenocarcinoma colorretal. Métodos - Estudo retrospectivo, tipo caso-controle, realizado na Fundação Pio XII, em Barretos, SP, utilizando-se base de dados de prontuários de 383 pacientes admitidos entre 1999 e 2003. Utilizou-se teste exato de Fischer ou qui ao quadrado para variáveis dicotômicas e $t$ de Student para variáveis contínuas, na análise univariada, adotando-se nível de significância de $10 \%(P \leq 0,10)$; na análise multivariada foi aplicado o teste de regressão logística múltipla, com nível de significância de 5\% $(P \leq 0,05)$; as razões de chances e os respectivos intervalos de confiança de $95 \%$ foram calculados. Resultados - Nas análises univariadas foram consideradas significantes as variáveis altura $(P=0,06)$, glicemia $(P=0,05)$, antecedente de cirurgia abdominal ou pélvica $(P=0,031)$, operação abdominoperineal $(P<0,001)$, cirurgia ampliada $(P<0,001)$ e intervenção com intuito radical $(P<0,001)$. Na análise multivariada por regressão logística foram considerados independentemente significantes, quando analisadas em conjunto, intervenção com intuito radical $(\mathrm{OR}=10,249, P<0,001$, IC $95 \%=3,071-34,212)$ e amputação abdominoperineal $(\mathrm{OR}=3,906, P=0,04, \mathrm{IC} 95 \%=$ 0,151-0,692). Conclusão - Esta investigação permitiu concluir que a intervenção radical e o procedimento abdominoperineal, no tratamento cirúrgico do adenocarcinoma colorretal, constituem fatores de risco independentes para a transfusão sanguínea intraoperatória.

DESCRITORES - Transfusão de sangue. Neoplasias colorretais. Cirurgia. Adenocarcinoma, cirurgia. 


\section{REFERENCES}

1. Amato A, Pescatori M. Perioperative blood transfusions for the recurrence of colorectal cancer (Cochrane review). In: The Cochrane Library, Issue 1, 2006. Oxford: Update Software.

2. Benoist S, Panis Y, Pannegeon V, Alves A, Valleur P. Predictive factors for perioperative blood transfusion in rectal resection for cancer: a multivariate analysis of a group of 212 patients. Surgery. 2001;129:433-9.

3. Blacjchman MA, Vamvakas EC. The continuing risk of transfusion-transmitted infections. N Eng J Med. 2006;355:1303-5.

4. Brasil. Ministério da Saúde. Instituto Nacional do Câncer - INCA, Estimativa da incidência e mortalidade por câncer. Rio de Janeiro: INCA; 2008.

5. Guillem JG, Cohen AM. Current issues in colorectal cancer surgery. Semin Oncol. 1999;26:505-13.

6. Guillem JG, Paty PB, Cohen AM. Surgical treatment of colorectal cancer. Ca J Clin. 1997; 47:113-28

7. Heiss MM, Tarabichi A, Delanoff C, Allgayer H, Jauch KW, Hernandez-Richter T, Mempel W, Beck KG, Schildberg FW, Messmer K. Perisurgical erythropoietin application in anemic patients with colorectal cancer: a double-blind randomized study. Surgery. 1996;119:523-7.
8. Henry DA, Carless PA, Moxey AJ, O'Connell D, Forgie MA, Wells PS, Fergusson D. Pre-operative autologous donation for minimising perioperative allogeneic blood transfusion. Cochrane Database Syst Rev. 2002;(2):CD003602.

9. Kockerling F, Reymond MA, Schneider C, Wittekind C, Scheidbach H, Konradt J, Köhler L, Bärlehner E, Kuthe A, Bruch HP, Hohenberger W. Prospective multicenter study of the quality of oncologic resections in patients undergoing laparoscopic colorectal surgery for cancer. The Laparoscopic Colorectal Surgery Study Group. Dis Colon Rectum. 1998;41:963-70.

10. Mynster T, Nielsen HJ, Harling H, Bülow S; Danish TME-group, RANX05-group Blood loss and transfusion after total mesorectal excision and conventional rectal cancer surgery. Colorectal Dis. 2004;6:452-7.

11. Nilson KR, Berenholtz SM, Dorman T, Garrett E, Lipsett P, Kaufman HS Pronovost PJ. Preoperative predictors of blood transfusion in colorectal cancer surgery. J Gastrointest Surg. 2002;6:753-62.

12. Okuyama M, Ikeda K, Shibata T, Tsukahara Y, Kitada M, Shimano T. Preoperative iron supplementation and intraoperative transfusion during colorectal cancer surgery. Surg Today. 2005;35:36-40 